\title{
Current Dynamics and Water Column Stability in Indonesian Waters Based on Hydrodynamics Model
}

\author{
Engki A Kisnarti ${ }^{1 *}$, Nining Sari Ningsih ${ }^{2}$, Mutiara R Putri ${ }^{3}$ and Nani Hendriati ${ }^{4}$ \\ 1,2,3Program Study of Earth Sciences, Faculty of Earth Sciences and Technology, Institute Technology of Bandung, Indonesia, \\ ${ }^{4}$ Coordinating Ministry for Maritime and Investment Affairs, Indonesia.
}

Received: 2020-10-05 Accepted: 2021-04-26

\section{Keywords:}

water masses;

density;

stability

Correspondent email:

engki.andri@hangtuah.ac.id

\begin{abstract}
Monsoon currents and Indonesian Throughflow (ITF) have an essential role in the current Indonesian water system. The movement of current/water masses with non-uniform bathymetric conditions will affect the water column's stability in Indonesian waters. Therefore, this study aims to obtain the current dynamics and stability of the water column in Indonesian waters, based on a hydrodynamic model termed the HAMburg Shelf Ocean Model (HAMSOM). The results of the model are data of current, temperature, salinity, and density. The data is used to study the dynamics of seawater in Indonesian waters. The water column's stability is examined by calculating the Brunt Väisälä frequency values $\left(\mathrm{N}^{2}\right)$ based on the density data generated. The results show that monsoon currents were stronger in shallow waters because the stratification did not change. Meanwhile, the maximum $\mathrm{N}^{2}$ value occurs at the surface to a depth of $80-100 \mathrm{~m}$ with a range of 0.0000-0.0006 cycle s ${ }^{-1}$. The study also produces an understanding of the condition of Indonesia's stability ( $\mathrm{N}^{2}$ positive), both spatially and temporally.
\end{abstract}

@2021 by the authors. Licensee Indonesian Journal of Geography, Indonesia.

This article is an open access article distributed under the terms and conditions of the Creative Commons

Attribution(CC BY NC) licensehttps://creativecommons.org/licenses/by-nc/4.0/.

\section{Introduction}

Current circulation in Indonesian waters is influenced by two main currents, including monsoon currents and Indonesian Throughflow (ITF). Besides, the monsoon currents generally flow east in the boreal winter (DecemberFebruary) and west in the boreal summer (July-August) towards the South China Sea (van Aken et al., 2009; Mayer et al., 2010; Susanto et al., 2013; Rejeki et al., 2018). The water mass also serves as a channel for inter-ocean water mass flow from the Pacific (in the north and northeast) to the Indian Ocean (in the south and southwest), observed at depths of 100-250 m (Wyrtki, 1987; Mayer et al., 2010; Susanto et al., 2012, Sprintall and Reveland, 2014). This transit also affects the surface (Susanto et al., 2012).

The water mass comprises layers formed by the composition of specific physical properties, including pressure, temperature, salinity, and density, consequently influencing overall stability (Pond and Pickard, 2013). Generally, the water mass density elevates with increasing depth, causing a stable water column in the ocean (strongly stratified). However, the dynamics possibly cause neutrality (not stratified) and instability (weak stratification), accompanied by vertical flow velocity differences. This phenomenon results in turbulence, categorized into mesoscale and micro-scale types, based on nature, spatialtemporal scale, the direction of mixing (isopycnal), and intensity (Monin and Ozmidov, 1985). Specifically, mesoscale turbulence is created due to instability, including baroclinic, barotropic, and others, and is known to occur along surfaces with constant density.
Meanwhile, micro-scale ensues through the shear and rupture of internal waves and generally occurs in a vertical direction. This incident controls the dynamics of global scale currents, vertical circulation exchange in estuaries and coastal areas, and air-sea interactions. Furthermore, the sheer mass mixing process is derived from the Brunt Väisälä $\left(N^{2}\right)$ frequency value or floating frequency.

Research on the water column's current dynamics and stability in Indonesian waters has been carried out in the ITF route, including the Makassar Strait, Lombok Strait, and the Celebes Sea. The results show strength at different depths of 100-125 m (Pujiana et al., 2009), 200-250 m, and 200-250 m (Firdaus et al., 2016 and Hermansyah et al., 2017), respectively. Meanwhile, research on current dynamics and water column stability representing the two main currents in Indonesia waters has not been developed. Hence, this research focuses on currents and water column stability dynamics in Indonesia's main currents, using current ocean models. Therefore, it aims to obtain current and stable Indonesia water dynamics based on the current hydrodynamic model.

\section{Methods}

\section{Hydrodynamic Model Design}

The research method involves the numerical modelling of HAMburg Shelf Ocean Model (HAMSOM) hydrodynamics, developed by Backhaus $(1983,1985)$. This model is a threedimensional (3D) baroclinic hydrodynamic verified in Indonesian waters (Putri, 2005; Putri et al., 2017; Anwar et 
al., 2017; Anwar et al., 2018). Furthermore, the simulation has previously been performed for a year (2013) under normal conditions (not influenced by El-Nino Southern Oscillation/ENSO) (Huang et al., 2017).

The bathymetry data input was processed directly from the world map obtained from the Shuttle Radar Topography Mission (Jarvis et al., 2008), with each horizontal size $d x, d y$ of 6 minutes $\left(1 / 10^{\circ}\right), d z$ by 20 vertical layers $(6,10,14,20,25$, $25,50,100,200,300,400,500,500,500,1000,1000,1000$, $1500,1500,2.000 \mathrm{~m}$ ), and $d t$ by 180 seconds. The domain model used is $20^{\circ} \mathrm{N}-15^{\circ} \mathrm{S}$ and $90^{\circ} \mathrm{E}-142^{\circ} \mathrm{E}$, with a grid number of $351 \times 521$. Furthermore, tidal data (constants: $M_{2}$ $=$ semi-diurnal principal lunar, $S_{2}=$ semi-diurnal principal solar, $K_{1}=$ diurnal principal lunar-solar, and $O_{1}=$ diurnal principal lunar) are used to generate force at the model area's open boundary. This was obtained from the Oregon State University Tidal Prediction Software (OPTS) global model (Egbert and Svetlana, 2002), with a horizontal resolution of $1^{\circ}$ $\mathrm{x} 1^{\mathrm{o}}$. The atmospheric parameters used as input include average sea level pressure, air temperature, specific humidity, total cloud cover, wind, and precipitation levels, obtained from the National Center for Environment Prediction (NCEP). NCEP data have a resolution of $2.5^{\circ} \times 2.5^{\circ}$ longitude/latitude, which happens to be an "ocean," not a "land" point, with data intervals of six hours (Kistler et al., 2001). Monthly temperature and salinity data with quarterdegrees (represent the world as 1440 x 720 quarter-degree longitude/latitude boxes) are obtained from the World Ocean Atlas (WOA) (Locarnini et al., 2013; Zweng et al., 2013). Furthermore, the atmospheric parameter, temperature, and salinity data were captured into the domain model to be used.

The hydrodynamics model simulation results' output is the current, temperature, salinity, and density data, which is a depth function. Density values were then interpolated to standard depth levels and objectively analyzed in the same manner as temperature and salinity in the World Ocean Atlas 2013 (Locarnini et al., 2013; Zweng et al., 2013).

This output is used to obtain current, temperature, salinity, and density circulation based on the monsoon currents system and ITF route. Therefore, the sea can be assumed as a layered fluid, assumed to allow the emergence of shear or differences in dynamic properties (represented by velocity in this case study) between layers. This also induces instability in the fluid system, thus leading to turbulence. Besides, water column stability is essential in representing competitive dominance between buoyancy and turbulence to ascertain stratification and mixing.

\section{Stability}

The water column stability is determined as the exchange rate of density against depth (Stewart, 2002):

$$
E=-\frac{1}{\rho} \frac{\partial \rho}{\partial z}
$$

where $r$ is density $\left(\mathrm{kg} \mathrm{m}^{-3}\right)$ and $z$ is depth $(\mathrm{m})$. If $\frac{\partial \rho}{\partial z}<0$ density is expected to increase with depth, and then $E>0$, thus validating the water column's stability. Under this condition, light water tends to be above the heavy one, characterized by vertical mass movement inhibition. Conversely, the water column is unstable when $\frac{d \rho}{d z}>0$, featuring a decline in density with depth, hence $E<0$. This phenomenon is observed when heavy water is above the mild variety, leading to a downward vertical mass movement. However, a neutral (neutral stability) column is indicated on instances where there is no change in density with depth,

$$
\frac{d \rho}{d z}=0
$$

The Brunt Väisälä frequency value (stability frequency) shows the oscillation frequency of isopycnal displacement fluctuations in unstable water masses (Pickard dan Emery, 1990). This serves as a determinant of stability and is calculated in terms of frequency squared $\left(N^{2}\right)$, (Messel, 1999; Pond and Pickard, 2013), using the formula:

$$
N^{2}=-\frac{g}{p_{\phi}} \frac{\partial \rho}{\partial z}
$$

Where 9 is Earth's gravitational acceleration $\left(9,8 \mathrm{~m} \mathrm{~s}^{-2}\right), r$ denotes density $\left(\mathrm{kg} \mathrm{m}^{-3}\right), z$ is depth $(\mathrm{m})$, and $r_{o}$ is background density of water. The water mass is assumed stable when $N^{2}$ has a positive value and unstable when negative, while a neutral column is confirmed with $\mathrm{N}^{2}=0$.

\section{Result and Discussion \\ Currents in Indonesian Waters}

Current simulation results show that the currents flow eastward in February (representing the boreal winter) into Indonesian waters from the South China Sea and run through the Natuna Sea to the Java Sea. These currents flow into the Flores Sea and through Banda out into the south of Papua Islands, although some currents move northward to the Pacific Ocean. There is the South Equatorial Current (SEC) westward throughout the year in the west of Sumatra. Likewise, there is also the SEC in the south of Java, and there is also a narrow strip along the south coast of Java (Java South Current/JSC), with the current heading east, as opposed to SEC (Fig 1a). In the Malacca Strait and the Sunda Strait, currents flow into the Indian Ocean. Conversely, the reverse is the case in August, as the current moves westward into the South China Sea. There is a strong SEC from the Pacific Ocean in Papua's north, then joint with the Equatorial Counter Current (ECC). In the Sunda Strait and coast of Nusa Tenggara, the outflow is towards the Indian Ocean (Fig. 1b). Despite using different simulation years (2007), in general, the simulation results show that the monsoon current pattern is almost the same as the monsoon current pattern in previous studies (Mustikasari et al., 2015).

In August (representing the boreal summer), the ITF flowed very strongly into Indonesian waters at a depth of 87 m. This entails flow from the Pacific Ocean (North Equatorial Current/NEC) through the Celebes Sea to the Makassar Strait (first/mainline) (Mayer et al., 2010; Susanto et al., 2012, Sprintall and Reveland, 2014). Therefore, distribution is indicated through two channels in the southern part. Subsequently, some exit through the Lombok Strait while others are moved eastward through the Flores to the Banda Seas. The currents further egress through the Ombai Strait and the Timor gap into the Indian Ocean.

The second entrance is through the Maluku Sea, where the current flows into the Banda Sea and exits through the Ombai Strait and the Timor gap. The following entry was through the Halmahera Sea, carried by the current into the Seram Sea, and through the Timor Gap egress into the Indian Ocean (Fig. 1b and 2). The entry of water masses from the 

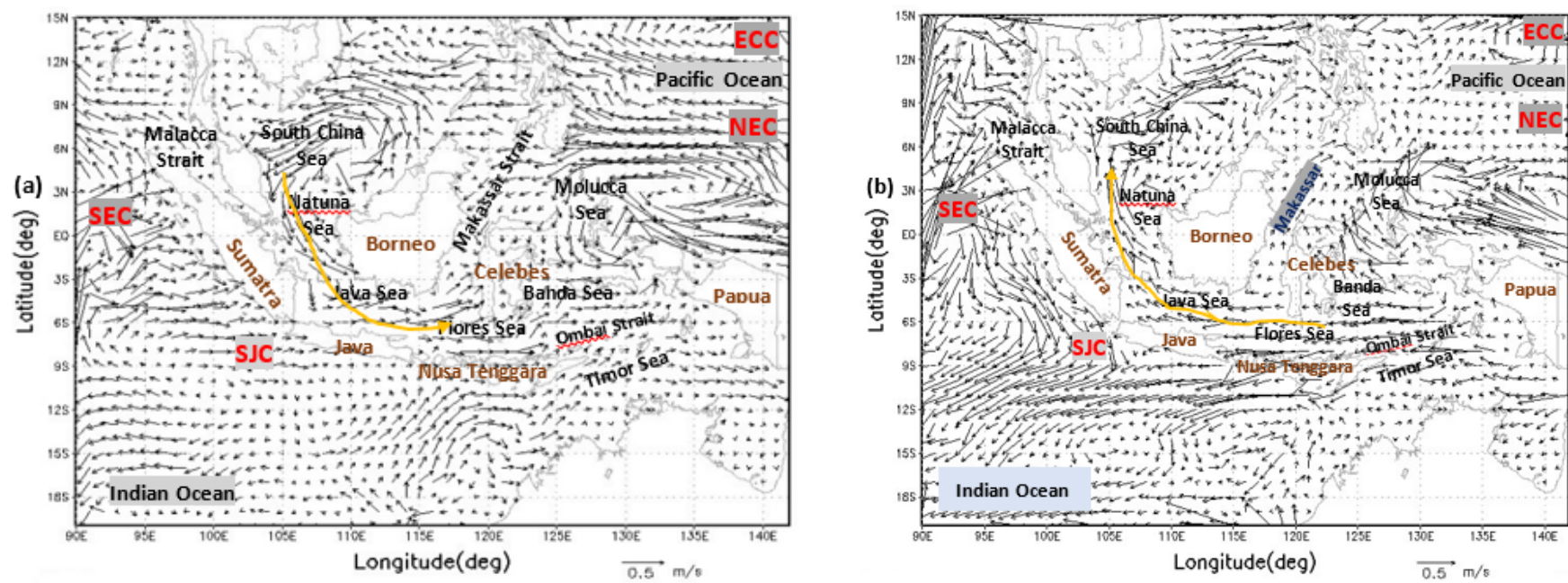

Figure 1. Monsoon currents HAMSOM simulation results (orange line): (a) February 2013 and (b) August 2013.

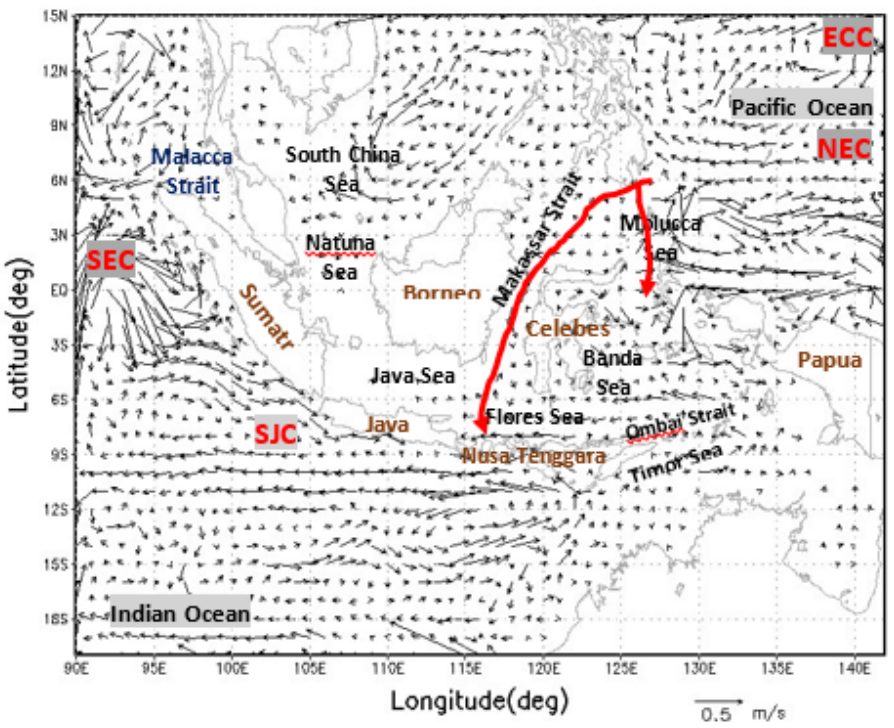

Figure 2. Currents at a depth of $87 \mathrm{~m}$ below sea level the simulation results of HAMSOM in August 2013 (red line is ITF).

Pacific Ocean to the Indian Ocean in this simulation is similar to previous studies' results (Gordon et al., 2008; Gordon et al., 2010). However, the ITF's strength is not as muscular as in their study, considering that this simulation was carried out under normal conditions.

Temperature, Salinity, and Density in Indonesian Waters

The low temperatures $\left(27^{\circ} \mathrm{C}\right)$ recorded in February originated from the South China Sea, through Natuna to the Java Sea, and were blocked by higher values observed southeast $\left(30^{\circ} \mathrm{C}\right)$. This phenomenon leads to an increase in the temperature of Natuna $\left(27-28^{\circ} \mathrm{C}\right)$ and Java $\left(28-29^{\circ} \mathrm{C}\right)$ sourced water. Meanwhile, the Pacific Ocean resource at $28^{\circ}$ $\mathrm{C}$ also entered Indonesian waters through the Makassar Strait and increased by $1^{\circ} \mathrm{C}$ southwards. Furthermore, a salinity of 34 Practical Salinity Unit (PSU) was recorded in Makassar Strait and the South China Sea, which extends south, through Natuna (33 PSU) to Java Sea (32.5-31.5 PSU). The values increased in value from 32 to 33.5 PSU in the north of Makassar Strait. Moreover, the 34 PSU isohaline line in the Celebes Sea is pushed back towards the Pacific Ocean (Fig. 3). (a)

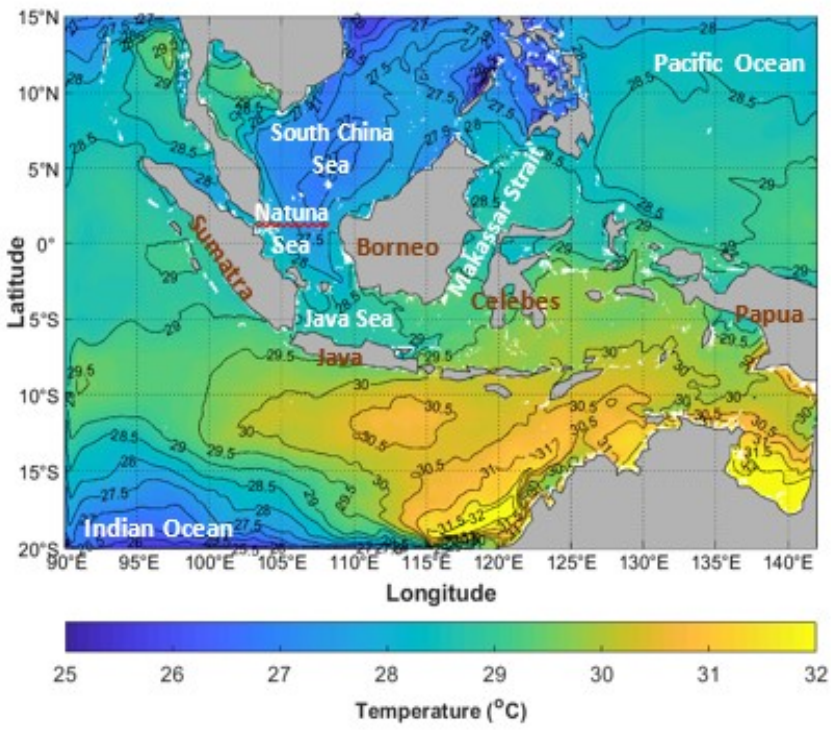

(b)

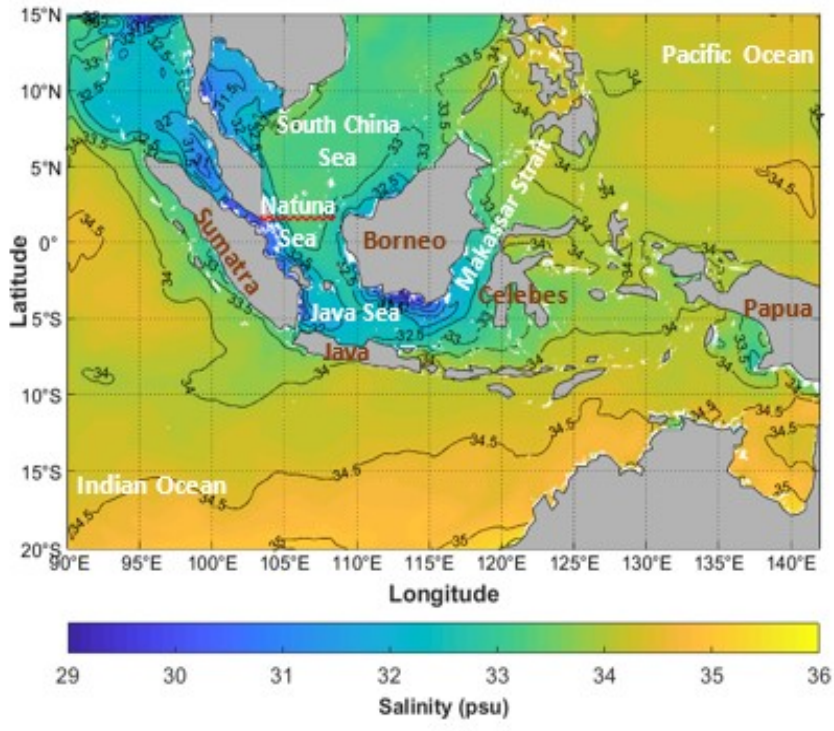

Figure 3.Monthly average sea surface: (a) temperature and (b) salinity in February 2013, the simulation result of HAMSOM. 
(a)

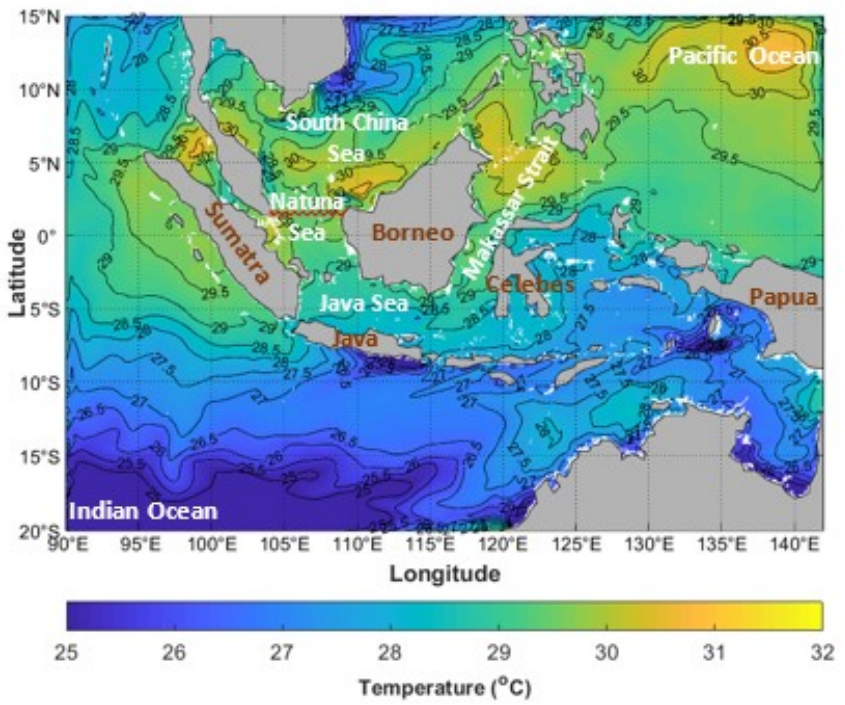

(b)

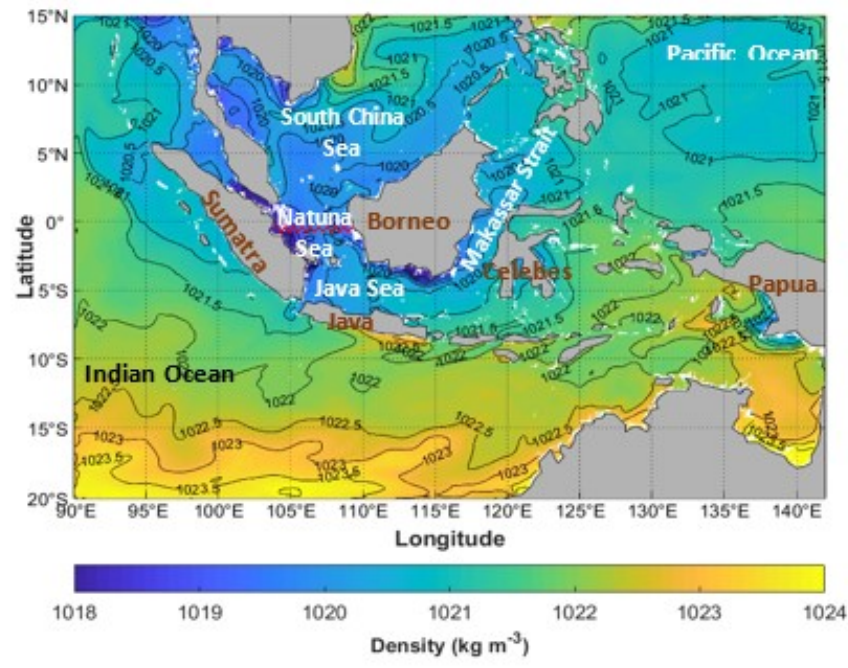

Figure 5. Monthly average sea surface density: (a) February and (b) August 2013, the simulation result of HAMSOM.

The values obtained depend on the water density and column depth, leading to varied maximum values at different depths in each location, considering Indonesian waters' nonuniform bathymetry. In February and August, the maximum $N^{2}$ value occurs at depths 6-20 $\mathrm{m}$ in western Indonesia, while in eastern Indonesia, it reaches a depth of $100 \mathrm{~m}$. Meanwhile, the maximum $N^{2}$ value in northern Papua reached a depth of $200 \mathrm{~m}$ in August (Figure 6).

The evaluation of these conditions requires vertical profile observation of the water column at locations considered necessary, including the Makassar Strait, known to channel water masses from the Pacific Ocean to the Indian Ocean. Simultaneously, the Java Sea is a passage from the South China Sea in the west to east monsoon. Besides, the vertical profile slices of the water column in the Makassar Strait were performed at three locations, comprising the

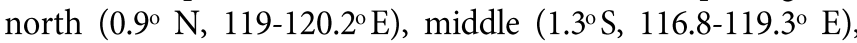
and south ( $\left.4^{\circ} \mathrm{S}, 116.2-119.5^{\circ} \mathrm{E}\right)$. Meanwhile, in the Java Sea, ensued in the west $\left(3.1-6^{\circ} \mathrm{S}, 106.8^{\circ} \mathrm{E}\right)$, middle (3-6.9 $\mathrm{S}$, $\left.110.5^{\circ} \mathrm{E}\right)$, and east $\left(3.4^{-7^{\circ}} \mathrm{S}, 112.7^{\circ} \mathrm{E}\right)$ (Figure 6).

\section{Water Column Stability}

In the north of the Makassar Strait, sea surface density values tend to be uniform, namely $1,021 \mathrm{~kg} \mathrm{~m}^{-3}$ in February (a)

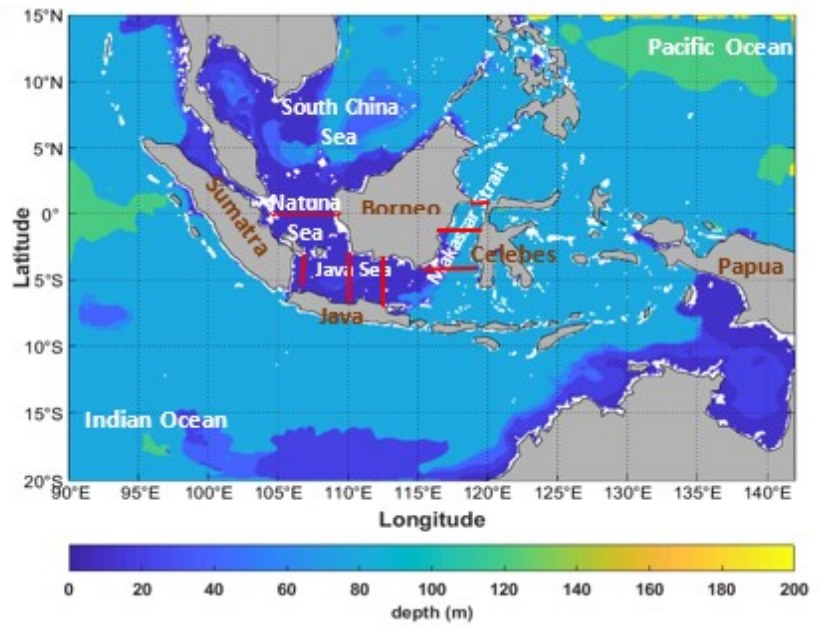

(b)

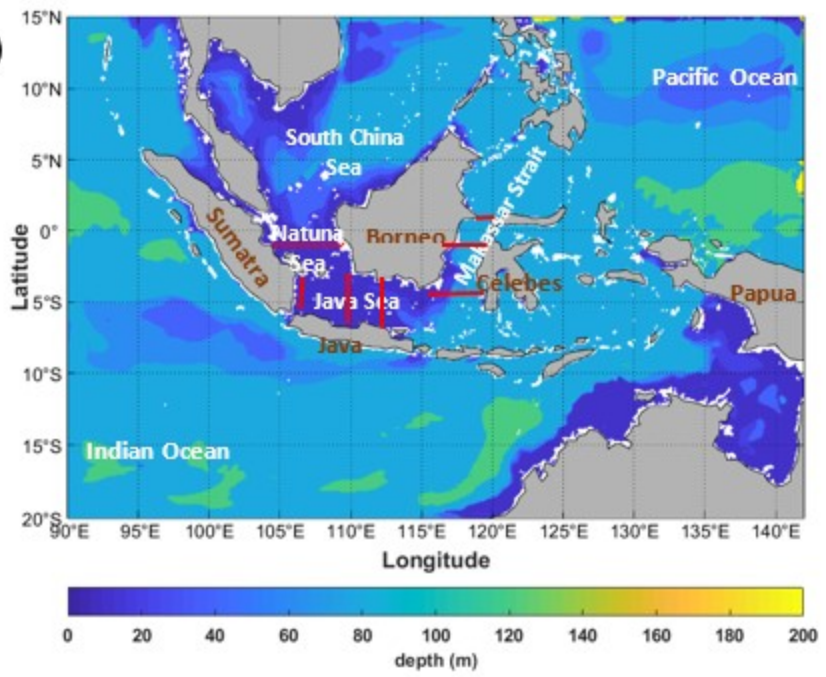

Figure 6. Monthly average of depths of the maximum $\mathrm{N}^{2}$ value in (a) February and (b) August 2013. The red lines show cross-sections to analyze the Brunt-Väisälä frequency values $\left(\mathrm{N}^{2}\right)$

and $1,020.5-1021 \mathrm{~kg} \mathrm{~m}^{-3}$ in August. Likewise, the maximum $N^{2}$ value at a depth of $100 \mathrm{~m}$. This condition is different from the central and southern Makassar Strait. The west's sea surface density value is lower than the density value in the northern Makassar Strait and tends to decrease to the south, namely: $1,020.5 \mathrm{~kg} \mathrm{~m}^{-3}$ in the middle and $1,020 \mathrm{~kg} \mathrm{~m}^{-3}$ in the south in February, and $1,020 \mathrm{~kg} \mathrm{~m}^{-3}$ in August. Meanwhile, the sea surface density value in the eastern part of the Makassar Strait from north to south only changed by 0.5 (from 1,021-1,020.5 kg m $\mathrm{kg}^{-3}$ ). This decline occurred in the southern part of the Makassar Strait. The maximum $N^{2}$ value is also the difference between the western and eastern parts of the Makassar Strait. The maximum $N^{2}$ value in the west occurs at depths $6-20 \mathrm{~m}$, while in the east, it appears at depths of $100 \mathrm{~m}$ (Fig. 6 \& 7).

Sea surface density values in the north of the Java Sea tend to be lower than in the south, namely: $1,018 \mathrm{~kg} \mathrm{~m}^{-3}$ in the east and continue to move up to $1,020 \mathrm{~kg} \mathrm{~m}^{-3}$ to the west in February. In August, the surface density value was only $1,019 \mathrm{~kg} \mathrm{~m}^{-3}$. In the southern part of the Java Sea, the surface density value only slightly changed from $1.020-1,021 \mathrm{~kg} \mathrm{~m}^{-3}$ (February and August). The water column's stability in the Java Sea tends to be the same, which occurs at a depth of 6-20 m (Fig. 6 and 8). 

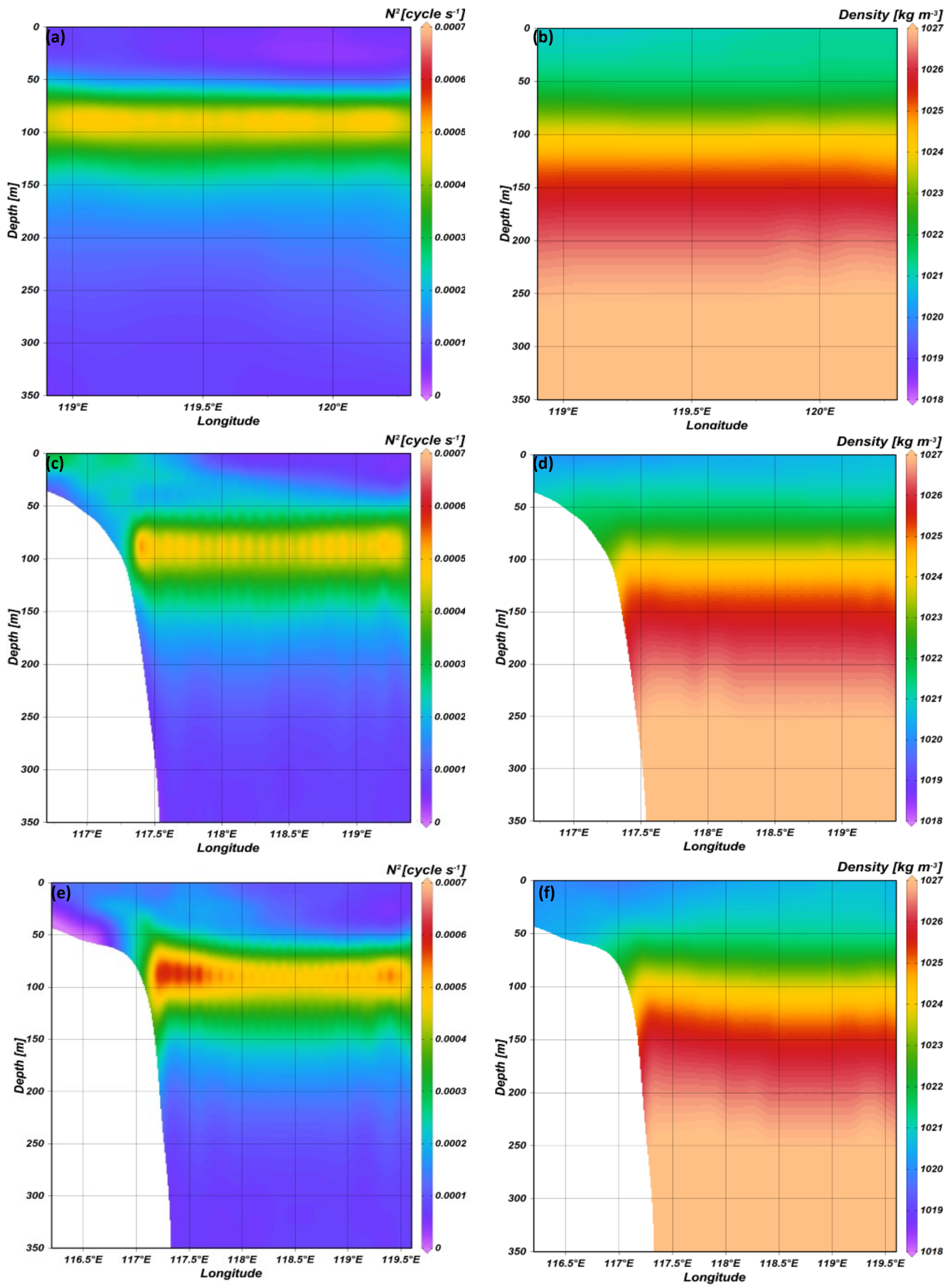

Figure 7. Vertical profile of average Brunt-Väisälä frequency values $\left(\mathrm{N}^{2}\right)$ and density in: $(\mathrm{a} \& \mathrm{~b})$ the northern, $(c \& d)$ the middle part, (e \& f) the southern of the Makassar Strait in February 2013. 

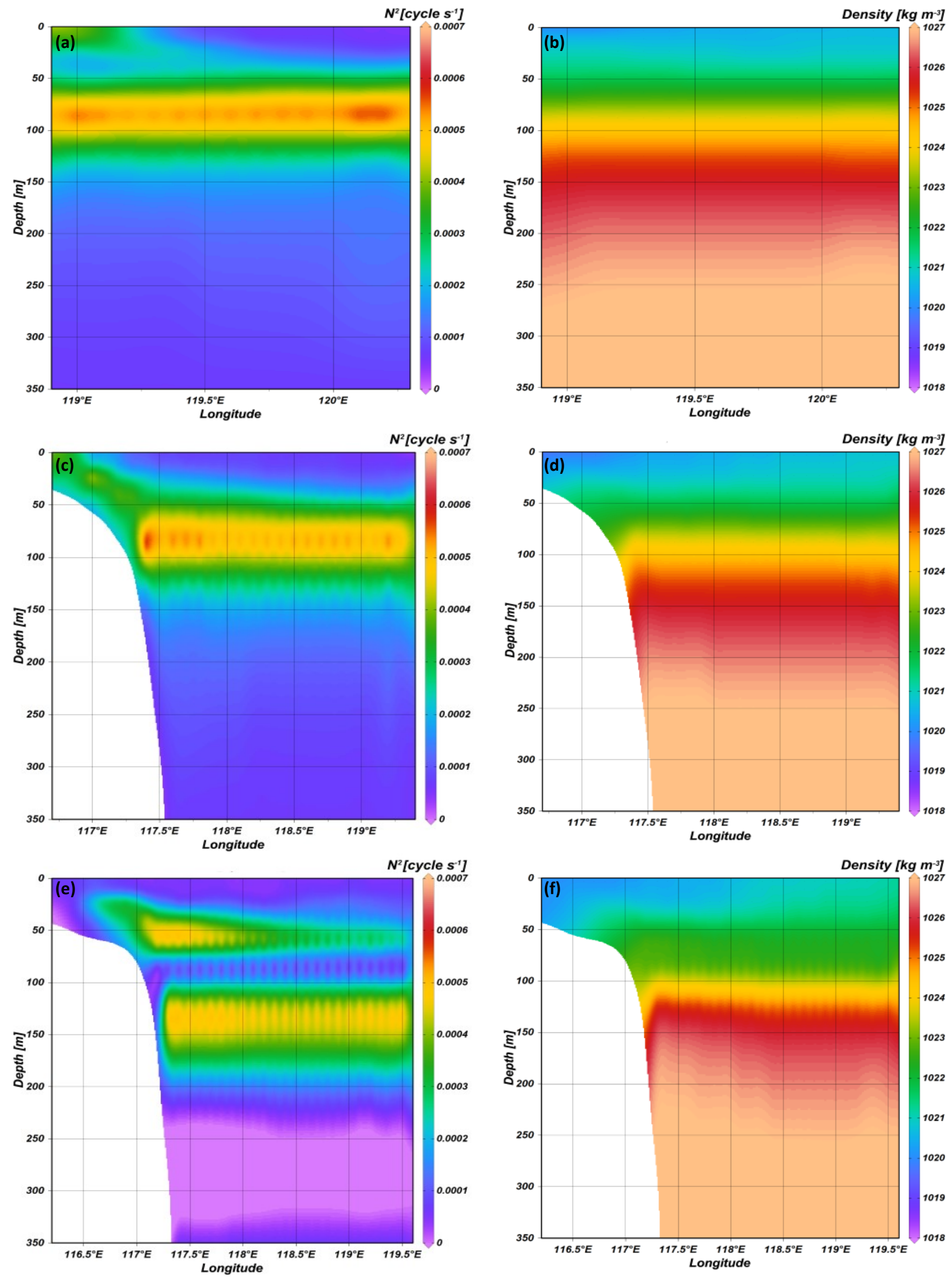

Figure 8. Vertical profile of average Brunt-Väisälä frequency values $\left(\mathrm{N}^{2}\right)$ and density in: $(\mathrm{a} \& \mathrm{~b})$ the northern, $(c \& d)$ the middle part, (e \& f) the southern of the Makassar Strait in August 2013. 

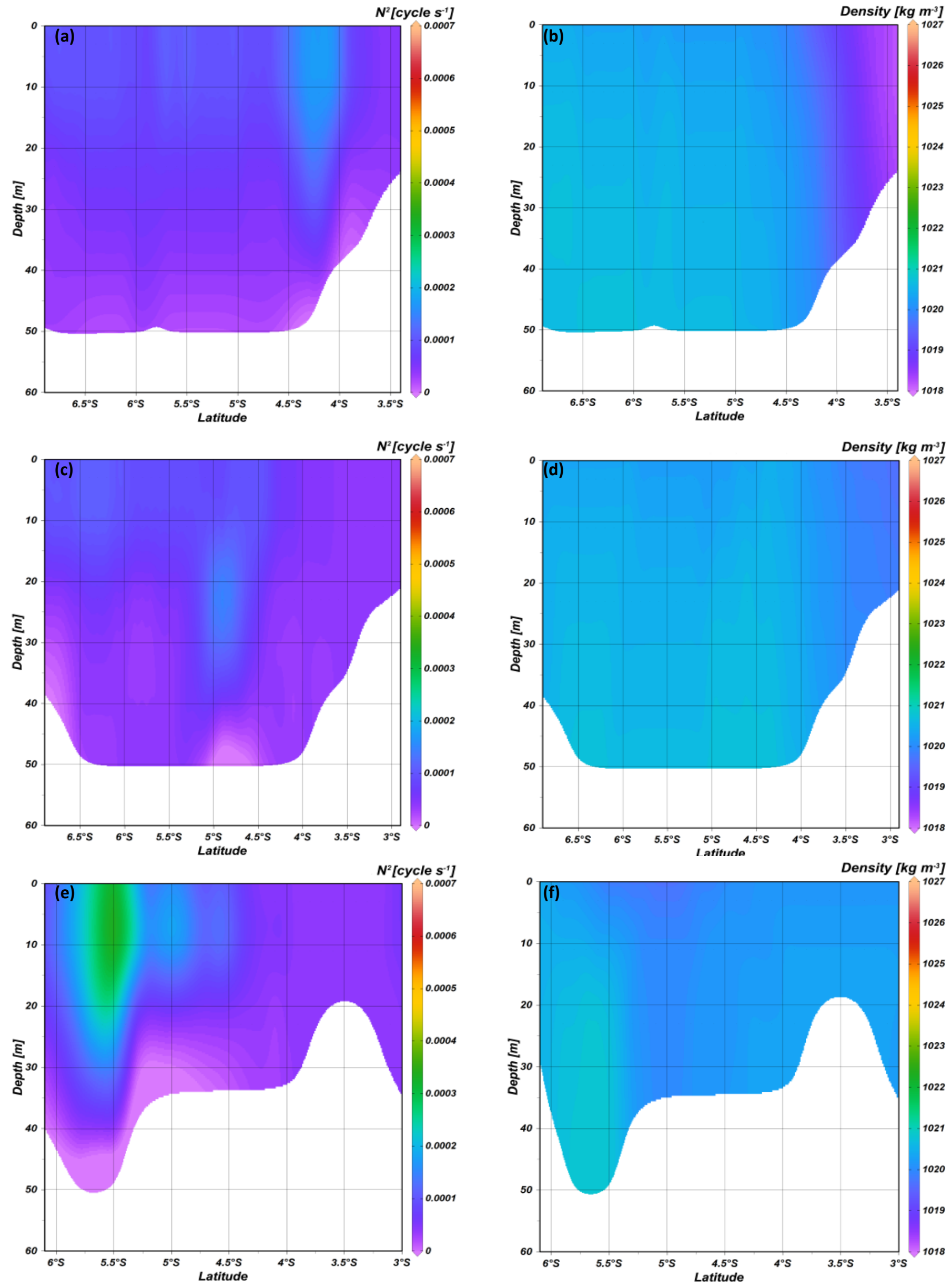

Figure 9. Vertical profile of average Brunt-Väisälä frequency values $\left(\mathrm{N}^{2}\right)$ and density in: $(\mathrm{a} \& \mathrm{~b})$ the eastern, (c \& d) the middle part, (e \& f) the western of the Java Sea in February 2013. 

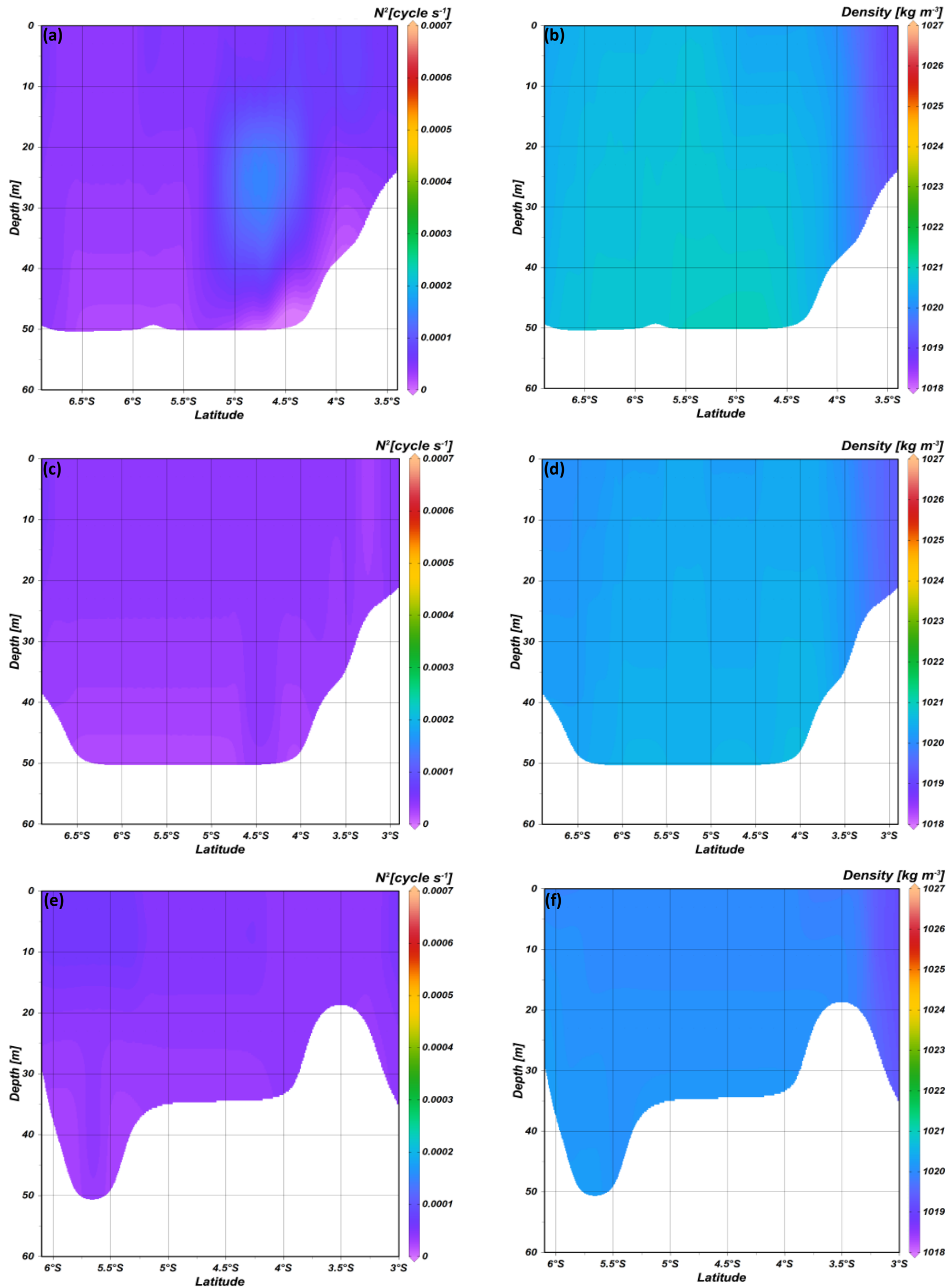

Figure 10. Vertical profile of average Brunt-Väisälä frequency values $\left(\mathrm{N}^{2}\right)$ and density in: $(\mathrm{a} \& \mathrm{~b})$ the eastern, $(\mathrm{c} \& \mathrm{~d})$ the middle part, (e \& f) the western of the Java Sea in August 2013. 
The $N^{2}$ value recorded in the Makassar Strait was within the range of $0.0005-0.0006$ cycle $\mathrm{s}^{-1}$ in February, at a depth of $80-100 \mathrm{~m}$, with $1,023-1,024 \mathrm{~kg} \mathrm{~m}^{-3}$ density. Also, the density value ranges from $1,019-1,022 \mathrm{~kg} \mathrm{~m}^{-3}$, and only to the west of the southern part of the Makassar Strait is the density of $1,018 \mathrm{~kg} \mathrm{~m}^{-3}$. This instigates water mass movement from rivers in Celebes, forcing the seawater to the middle of the sea. In contrast, in August, the maximum $N^{2}$ value slightly decreased compared to February (0.0004-0.0005 cycle s ${ }^{-1}$ ) and occurred at a depth of 50-100 m with a density of 1,023-1,024 $\mathrm{kg} \mathrm{m}^{-3}$, but in the southern part of the Makassar Strait, the maximum value of $N^{2}$ is found at depths of 40-60 and 120160 m. (Fig. 7).

A comparison of both months shows the maximum $N^{2}$ value at a depth of $50-160 \mathrm{~m}$ in August. This was due to the decisive entry of ITF into the Makassar Strait at depths of \pm 150 m (Susanto et al., 2012; Sprintall and Revelard, 2014; Mayer et al., 2015). This water mass determines the highest possible column stability at a depth of 50-100 m. Meanwhile, the results of previous studies indicate that the maximum water column stability in the Makassar Strait occurs at a depth of 100-125 m (Pujiana, 2009). This difference occurs due to differences in simulation years when the sea is in normal conditions. Simultaneously, previous research results were carried out when the sea was in abnormal conditions (ENSO effect). When viewed from both months' results, the appearance of maximum $N^{2}$ values on the surface in August was due to the month's low rainfall. Also, conditions in the area (west of the Makassar Strait) are shallow areas $(<50 \mathrm{~m})$. Therefore, to prove that bathymetry also plays a role in determining the maximum $\mathrm{N}^{2}$ location, the following site to be analyzed is the Java Sea.

The maximum $N^{2}$ of the Java Sea achieved in February had an average of less than 0.0001 cycle $\mathrm{s}^{-1}$. Only a few locations have an extreme value tendency. An extreme maximum $N^{2}$ value $\left(0.0004\right.$ cycle $\left.\mathrm{s}^{-1}\right)$ occurred in the western part of the Java Sea with sites $106.6^{\circ} \mathrm{E}, 5.5^{\circ} \mathrm{S}$, and eastern part of the Java Sea with $112.7^{\circ} \mathrm{E}, 6.8-7.0^{\circ} \mathrm{S}$ (near Java) and $112.7^{\circ} \mathrm{E}, 4.0-4.5^{\circ} \mathrm{S}$ (near Borneo Island). Meanwhile, in the central part of the Java Sea, the maximum $N^{2}$ value $\left(<0,0002\right.$ cycle s$\left.^{-1}\right)$ shifted slightly at a depth of 20$30 \mathrm{~m}\left(110.5^{\circ} \mathrm{E}, 4.7-5.0^{\circ} \mathrm{S}\right)$. The maximum $N^{2}$ value in August still occurs at the surface, although it has decreased compared to February. However, at locations $112.7^{\circ} \mathrm{E}$, 4.5$5.0^{\circ} \mathrm{S}$, the maximum $N^{2}$ value is slightly stronger. This condition occurs because of the decreasing value of rainfall (dry season) so that the mass of water from the sea pushes the mass of water from the land toward the coast. Meanwhile, the surface density value is $1,020-1,021 \mathrm{~kg} \mathrm{~m}^{-3}$ in both months. But in August, the surface density value in the north of the Java Sea (near Borneo Island) reached $1,018 \mathrm{~kg} \mathrm{~m}^{-3}$ (Fig. 9-10).

The low water column stability recognized in August resulted from the influx of solid ITF through the Makassar Strait with high density to the Java Sea, therefore replacing the new layer inflow from the west monsoon (Siregar et al. , 2017). This incident causes the mixing of volume and driving reduced water column stability. Conversely, the lowest ITF transport is recorded in February (Wyrtki, 1987). The lowdensity water mass from the South China Sea enters the Java Sea's eastern region (Siregar et al., 2017). However, the incident is not as strong as seen in August. This occurrence is responsible for the relatively higher $N^{2}$ value in February.

The discussion above shows stable water column conditions based on the density arrangement. The results demonstrate lighter values on the surface and successive increases significantly, indicating the water column stability by evaluating the maximum $N^{2}$. Besides, the dominant value in Makassar Strait was recorded at 80-100 m (deep water), mainly an isopycnal area. Similar manifestations were documented superficially, especially for regions with shallow water located near the island. Meanwhile, the highest $N^{2}$ value in the Java Sea was observed on the surface; hence, the water's depth influences the sample density determination.

\section{Conclusion}

The current system in Indonesia, especially on the surface, flows west in February and east in August (monsoon currents). On the surface of Indonesian waters, this monsoon current is very influential. The effect is more potent in shallow waters, such as the Java Sea, because there is no change from the stratification side. The sea surface density of $1,018-1,022 \mathrm{~kg} \mathrm{~m}^{-3}$ and will increase with increasing depth. The results show that Indonesian waters are a stable water column. For deep waters, represented by the Makassar Strait, which is also the main route of the ITF, stable conditions are extreme at depths of 80-160 m. Conversely, stable conditions are harsh for shallow waters (Java Sea) occurring at depths of 6-20 m.

The results of this study can provide input on the stability of water masses in all Indonesian waters, considering that research on water masses in Indonesia is still local (more research is in the Makassar Strait). It is hoped that the stability of the water column and currents in Indonesian waters can be further developed, for example, for research on monitoring pollutants at sea level.

\section{Acknowledgment}

We extend our thanks to the Institute Technology of Bandung, University of Hang Tuah, and Domestic Postgraduate Education Scholarships-Ministry of Research and Technology- Higher Education (BPP DNRISTEKDIKTI) for providing moral and financial support in facilitating this research.

\section{References}

Anwar, I.P., M.R. Putri, and A. Setiawan, (2017) Variasi transpor volume dan variabilitas arus laut di Selat Karimata dan Gaspar tahun 2010-2014 berdasarkan model numerik.- Jurnal Ilmu dan Teknologi Kelautan Tropis, 9 (2), 771-782. DOI: http:// dx.doi.org/10.29244/jitkt.v9i2.19309.

Anwar, I.P., M. R. Putri, and A. Setiawan, (2018). Ocean numerical model experiment on estimating the variation of volume and heat transport in Karimata Strait.- IOP Conference Series: Earth and Environmental Science, 1-6, https://doi.org/10.1088/17551315/162/1/012001.

Backhaus, J.O.,(1983). A semi-implicit scheme for the shallow water equations for application to shelf sea modeling.- Continental Shelf Research, 2 (4), 243-254. DOI: https:// doi.org/10.1016/0278-4343(82)90020-6.

Backhaus, J.O., (1985). A three-dimensional model for the simulation of shelf sea dynamics, Deutsche Hydrographische Zeitschrift.

Bahiyah, A., A. Wirasatriya, J. Marwoto, G. Handoyo, and A. Anugrah, (2019). Study of seasonal variation of sea surface salinity in Java Sea and its surrounding seas using SMAP 
satellite.- IOP Conf. Series: Earth and Environmental Science, 246, 012043, 1-12. DOI: 10.1088/1755-1315/246/1/012043.

Egbert, G.D., and S.Y. Erofeeva, (2002). Efficient inverse modeling of barotropic ocean tides.- Journal of Atmospheric and Oceanic Technology, 19.2: 183-204. DOI: https://doi.org/10.1175/15200426(2002)019<0183:EIMOBO>2.0.CO;2.

Firdaus, R., H. Setiyono, and G. Harsono, (2016). Karakteristik massa air lapisan tercampur dan lapisan termoklin di Selat Lombok pada bulan November 2015- Jurnal Oseanografi, 5, 4, 425-434. http://ejournal-s1.undip.ac.id/index.php/jose.

Gordon, A.L., R.D. Susanto, A. Ffield, B.A. Huber. W. Pranowo, and S. Wirasantosa, (2008). Makassar Strait throughflow, 2004 to 2006.- Geophysical Research Letters, 35, L24605, 1-5. DOI: 10.1029/2008GL036372, 2008.

Gordon, A.L., J. Sprintall, H.M. van Aken, D. Susanto, S. Wijffels, R. Molcard, A. Ffield, W. Pranowo, and S. Wirasantosa, (2010). The Indonesian throughflow during 2004-2006as observed by INSTANT program.- Dynamics of Atmospheres and Oceans, 50, 115-128. DOI: 10.1016/j.dynatmoce.2009.12.002.

Hermansyah, H., A.S. Atmadipoera, T. Prartono, I. Jaya, and F. Syamsudin, (2017). Stratification and stability of seawater mass in Sulawesi Sea- International Journal of Sciences Basic and Applied Research, 36, 8 36-44.

Horii T., I. Ueki, and K. Ando, (2020). Coastal upwelling events, salinity stratification, and barrier layer observed along the southwestern coast of Sumatra.- Journal of Geophysical Research: Oceans, 125, e2020JC016287. DOI: https:// doi.org/10.1029/2020JC016287.

Huang, B., P.W. Thorne, V. F. Banzon, T. Boyer, G. Chepurin, J.H. Lawrimore, M.J. Menne, T.M. Smith, R.S. Vose, and H. Zhang, (2017) Extended Reconstructed Sea Surface Temperature, Version 5 (ERSSTv5): Upgrade, Validations, and Intercomparisons.- J. Climate, 30(20): 8179-8205. DOI: https:// doi.org/10.1175/JCLI-D-16-0836.1.

Kistler, R., E. Kalnay, W. Collins, S. Saha, G. White, J. Woollen, M. Chelliah, W. Ebisuzaki, M. Kanamitsu, V. Kousky, H. van den Dool, R. Jenne, and M. Fiorino, (2001). The NCEP-NCAR 50year reanalysis: Monthly means CD-ROM and Documentation.Bulletin of the American Meteorological Society, 82 (2), 247267.

Jarvis, A., H.I. Reuter, A. Nelson, and E. Guevara, (2008). Hole-filled seamless SRTM data V4.- International Centre for Tropical Agriculture (CIAT). http://www.cgiar-csi.org/data/srtm-90mdigital-elevation-database-v4-1.

Locarnini, R.A., A.V. Mishonov, J.I. Antonov, T.P. Boyer, H.E. Garcia, O.K. Baranova, M.M. Zweng, C.R. Paver, J.R. Reagan, D.R. Johnson, M. Hamilton, and D. Seidov, 2013. World Ocean Atlas (2013). Volume 1: Temperature. S. Levitus, Ed., A. Mishonov Technical Ed.; NOAA Atlas NESDIS 73, 40 pp. Publication DOI:10.7289/V55X26VD, dataset DOI:10.7289/ V5F769GT.

Mayer, B., P.E. Damm, T. Pohlmann, and S. Rizal., (2010). What is driving the ITF? An illumination of the Indonesian throughflow with a numerical nested model system.- Dynamics of atmospheres and oceans, 50 (2), 301-312. DOI: https:// doi.org/10.1016/j.dynatmoce.2010.03.002.

Messel, S.R., (1999). Fluid Mechanics for Marine Ecologist, Springer, Germany.

Monin, A.S., and R.V. Ozminov, (1985). Turbulence in the Ocean. D.

Reidel Pubs. Comp. Dordrecht

Mustikasari, E., L.C. Dewi, Heriati, A., and W.S. Pranowo. (2015). Pemodelan pola arus barotropik musiman 3 dimensi (3D) untuk mensimulasikan fenomena upwelling di perairan Indonesia.- Jurnal Segara, 11 (1), 25-35.

Pond, S., and G.L. Pickard, (2013). Introductory dynamical oceanography. $2^{\text {nd }}$ edition. Pergamon Press. Toronto.

Pujiana, K., A. L. Gordon, J. Sprintall, and R.D. Susanto, (2009). Intraseasonal variability in the Makassar Strait thermocline.-
Journal of Marine Research, 67 (6), 757-777. DOI: $10.1357 / 002224009792006115$.

Putri, M.R., (2005). Study of ocean climate variability (1959-2002) in the Eastern Indian Ocean, Java Sea, and Sunda Strait using the HAMburg Shelf Ocean Model, Disertasi Program Doktor, Universitat Hamburg.

Putri, M.R., A. Setiawan, T. Sari, B. Mayer, and T. Pohlmann, (2017). Trajectory model for identification of oil spill around the coast of Pari Island, Seribu Islands, North Jakarta.- Jurnal Ilmu dan Teknologi Kelautan Tropis, 9 (2), 657-664. DOI: https://doi.org/10.29244/jitkt.v9i2.19299.

Rejeki, H.A., Kunarso, and Munasik, (2018). Interannual variability of sea surface height difference between western Pacific Ocean and eastern Indian Ocean and its effect to geostrophic current in Lombok Strait.- IOP Conference Series: Earth and Environmental Science, 162 012016. DOI:10.1088/17551315/162/1/ 012016.

Siregar, N.S., P.L. Sari, N.P. Purba, W.S. Pranowo, and M.L. Syamsuddin, (2017). Pertukaran massa air di Laut Jawa terhadap periodisitas monsun dan Arlindo pada tahun 2015. Depik-Jurnal Ilmu-Ilmu Perairan, Pesisir, dan Perikanan. 6(1): 44-59. DOI: https://doi.org/10.13170/depik.6.1.5523.

Sjarif, S., (2018). Seasonal fluctuations in the surface salinity along the coast of the southern part of Kalimantan (Borneo).- Marine Research in Indonesia, 4(1). DOI: 10.14203/mri.v4i0.330.

Sprintall, J. and A. Revelard, (2014). The Indonesian throughflow response to Indo-Pacific climate variability.- Journal of Geophysical Research: Oceans, 1161-1174. DOI: https:// doi.org/10.1002/2013JC009533.

Stewart, R. H., (2002). Introduction to physical oceanography. Texas A \& M University: Department of Oceanography.

Susanto, R.D., A. Ffield, A.L. Gordon, and T.R. Adi, (2012). Variability of Indonesian throughflow within Makassar Strait, 2004 - 2009.- Journal of Geophysical Research, 117 (July), 349364. DOI: https://doi.org/10.1029/ 2012JC008096.

Susanto, R.D., W. Zexun, A. Rameyo, F. Bin, L.I. Shujiang and F. Guohong, (2013). Observations of the Karimata Strait throughflow from December 2007 to November 2008.- Acta Oceanologica Sinica, 32 (5), 365-370. DOI: 10.1007/s13131-013 -0307-3.

van Aken, H.M., I.S. Brodjonegoro, and I. Jaya, (2009). The deepwater motion through the Lifamatola Passage and its contribution to the Indonesian throughflow.- Deep-Sea Research Part I, 56 (8), 1203-1216. DOI: https:// doi.org/10.1016/j.dsr.2009.02.001.

Wyrtki, K., (1987). Indonesian through flow and the associated pressure gradient- Journal of Geophysical Research, 92 (C12), 12941. DOI: https://doi.org/10.1029/ JC092iC12p12941.

Zweng, M.M., J.R. Reagan, J.I. Antonov, R.A. Locarnini, A.V. Mishonov, T.P. Boyer, H.E. Garcia, O.K. Baranova, D.R. Johnson, D. Seidov, and M.M. Biddle, (2013). World Ocean Atlas 2013, Volume 2: Salinity. S. Levitus, Ed., A. Mishonov Technical Ed.; NOAA Atlas NESDIS 74, 39 pp. 